підвищити показник фондовіддачі, а також збільшити прибуток від реалізації продукції, а також рентабельність основних засобів організації.

Висновок. Отже, слід відмітити, що основні засоби - один із найважливіших чинників будь-якого виробництва. Їх стан i ефективне використання прямо впливають на кінцеві результати господарської діяльності підприємства.

Отож, ревізія і контроль основних засобів на підприємстві є важливою. Дана робота ревізора $є$ трудомісткою та має свої специфічні особливості. Ревізор повинен дотримуватись чинного законодавства, порядку перевірки основних засобів, обрати джерела інформації для ревізії, провести контроль за відображенням основних засобів та нарахованої амортизації на рахунках бухгалтерського обліку, а також враховувати реалії при здійсненні перевірки.

Список використаних джерел

1. Бистро В. В. Ревізія основних засобів на підприємстві / В. В. Бистро. // Управління розвитком. - 2014. - №175. - С. 23-26.

2. Бутинець Ф. Ф. Контроль та ревізія : підруч. [для студ. вищ. навч. закл.] / Ф. Ф. Бутинець, С. В. Бардаш, Н. М. Малюга. - Житомир: Світ, 2012. - 458 с.

3. Економічна статистика [Електронний ресурс]. - 2015. - Режим доступу до ресурсу: http://www.ukrstat.gov.ua/.

4. Інструкція про застосування Плану рахунків бухгалтерського обліку активів, капіталу, зобов/'язань і господарських операцій підприємств і організацій [Електронний ресурс]. - 2011. - Режим доступу до ресурсу: http://zakon5.rada.gov.ua.

5. Козел Т. В. Економічний зміст основних засобів як об'єкта обліку і контролю / Т. В. Козел. // Науковий вісник НЛТУ. - 2013. - №23. - С. 292-296.

Науковий керівник: д.е.к., проф. Дорош Н.I. Стаття відправлена: 29.03.2017 г.

(C) Ратушенко O.I.

\title{
ЦИТ: иа117-044
}

DOI: 10.21893/2415-7538.2016-05-1-044

ВНУТРІШНЙ КОНТРОЛЬ РОЗРАХУНКІВ 3 ПОКУПЦЯМИ ТА ЗАМОВНИКАМИ

Київський національний університет ім. Тараса Шевченка, Киів, Васильківська 90А, 03022

Kopanchuk K.V.

\section{INTERNAL CONTROL SETTLEMENTS WITH BUYERS AND CUSTOMERS}

Taras Shevchenko National University of Kyiv, Kyiv, Vasylkivska St 90A, 03022

Анотація. В статті розглядаються актуальні питання організації внутрішнього контролю розрахунків з покупиями та замовниками на підприємстві. Розкривається сутність та мета проведення 
внутрішньогосподарського контролю розрахунків з покупцями та замовниками, наводяться джерела інформаџії для проведення контролю. Розглянуто основні завдання внутрішнього контролю на підприємстві. Узагальнено об'єкти та систематизовано етапи проведення контролю розрахунків з покупцями та замовниками.

Ключові слова: внутрішній контроль, дебіторська заборгованість, розрахунки, покупці, замовники.

Abstract. In this paper we describe topical issues of internal control settlements with buyers and customers in the enterprise. We investigated the essence and purpose of internal control settlements with buyers and customers and sources of information for monitoring. We describe tasks of internal control in the company. Overview objects and systematized stages of monitoring settlements with buyers and customers.

Key words: internal control, receivables, payments, buyers, customers.

Вступ. У процесі реалізації підприємством матеріальних цінностей та надання послуг виникають розрахункові відносини 3 покупцями та замовниками. Від правильної організації цих розрахунків значною мірою залежить організація матеріального забезпечення i постачання. Внутрішньогосподарський контроль розрахунків 3 покупцями та замовниками дозволяє ефективно та мобільно віднайти недоліки в системі обліку та реалізації дебіторської заборгованості.

Основний текст. Аналіз наукової літератури свідчить, що трактування внутрішнього контролю у різних джерелах дається по різному. Відповідно до Міжнародного стандарту аудиту (MCA) 315, внутрішній контроль - це процес, який визначається i на який впливають особи, наділені повноваженнями управління та найвищого управління, а також інший персонал, який надає обгрунтовану впевненість щодо досягнення цілей суб'єкта господарювання стосовно: достовірності фінансової звітності, ефективності діяльності, дотримання застосовуваних законів та нормативних актів[1]. За визначенням Гуцаленко Л.В., внутрішньогосподарський контроль є основним джерелом інформаційного забезпечення управління підприємства, який розробляється власником та спрямований на: забезпечення дотримання законності й економічної доцільності здійснення операцій; збереження майна; попередження, виявлення i виправлення суттєвих помилок та викривлень інформації; належне формування облікових даних та звітності [3, ст. 112]. На основі досліджених публікацій доцільно сформувати власне визначення внутрішнього контролю, а саме: внутрішній контроль розрахунків з покупцями та замовниками - це система постійного спостереження за ефективністю, законністю та доцільністю господарських операцій і процесів, збереженням грошових коштів і матеріальних цінностей.

Метою внутрішнього контролю розрахунків з покупцями та замовниками $\epsilon$ забезпечення систематичного спостереження: за достовірністю облікових та звітних даних про наявність i зміну сум дебіторсько-кредиторської заборгованості; своєчасністю перерахування коштів кредиторам i відшкодування належних боргів дебіторами; правильністю пред'явлення 
претензій i вчасністю їх погашення, дотриманням розрахунково-платіжної дисципліни на рівні її впливу на платоспроможність підприємства [3, ст.124].

Основні завдання контролю розрахунків 3 покупцями та замовниками наведено на рис 1.

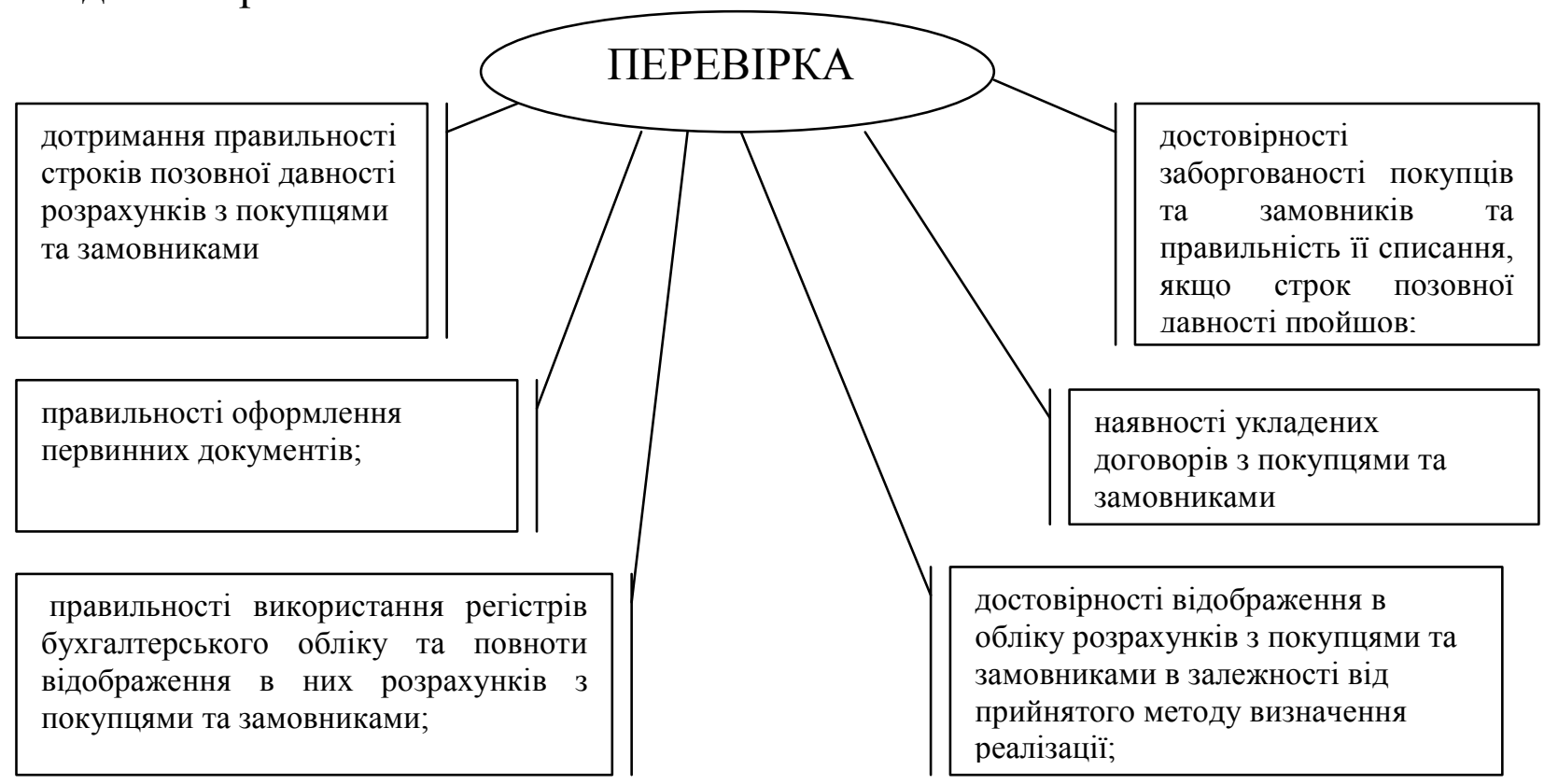

Рис 1. Основні завдання контролю розрахунків з покупцями та замовниками

Джерело: розроблено автором на основі [2].

Об’єкти контролю розрахунків 3 покупцями та замовниками класифікуються наступним чином (рис 2).

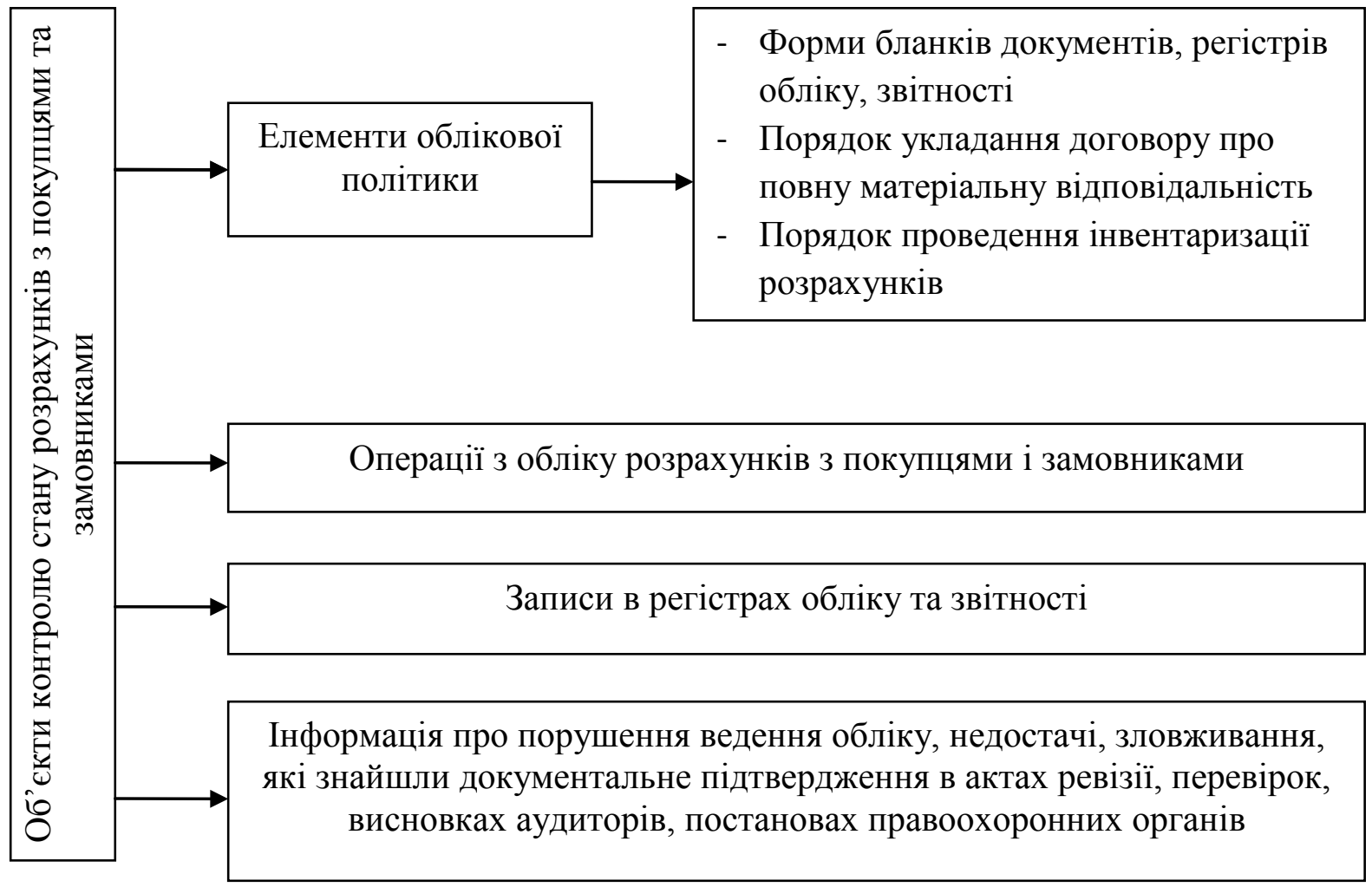

Рис 2. Об’єкти контролю розрахунків 3 покупцями та замовниками.

Джерело: розроблено автором на основі [4]. 
Джерелами інформації для контролю операцій з покупцями і замовниками є: первинні документи (договори, рахунки-фактури, видаткові накладні, акти приймання-здачі виконаних робіт, податкові накладні, товарно-транспортні накладні); облікові регістри (Журнал № 3 та Відомості аналітичного обліку розрахунків з покупцями 3.1, аналітичного обліку розрахунків з дебіторами 3.2 , аналітичного обліку виданих і отриманих авансів 3.4 та аналітичного обліку розрахунків за виданими операціями 3.5 ); форми фінансової звітності підприємства (Баланс (Звіт про фінансовий стан), Звіт про рух грошових коштів (за непрямим методом) та Примітки до річної фінансової звітності.); дані інвентаризації, акти звірки розрахунків тощо.

Стандартна форма етапів формування та проведення внутрішнього контролю передбачає наступну послідовність дій: встановлення нормативних показників; вимірювання фактичних результатів; порівняння результатів 3 нормативними показниками; аналіз розбіжностей та здійснення за необхідності коригуючих дій. Послідовність здійснення контролю розрахунків 3 покупцями та замовниками представлено на рис 3.

Послідовність контролю розрахунків з покупцями та замовниками

(1) Перевірка виконання договірних зобов'язань за операціями з реалізації готової продукції, товарів, виконаних робіт та наданих послуг

2 Дослідження динаміки заборгованості за операціями з постачання готової продукції, товарів, виконання робіт та надання послуг

3 Перевірка повноти та своєчасності проведення інвентаризацій розрахунків 3 покупцями та замовниками

4 Оцінка реальності, достовірності й документальної обгрунтованості кожної суми виникнення розрахунків

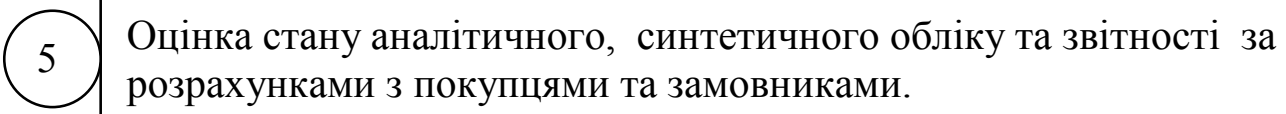

\section{Рис 3. Послідовність контролю розрахунків} з покупцями та замовниками

Джерело: розроблено автором на основі [5].

Висновки. В статті розглянуто основні питання організації контролю розрахунків з покупцями та замовниками. Досліджено сутність та мету проведення контролю, визначено основні завдання та етапи здійснення внутрішнього контролю розрахунків з покупцями та замовниками. Варто зазначити, що на даному етапі українські підприємства мають дуже великі обсяги дебіторської заборгованості за продукцію, товари, роботи і послуги, що значно погіршує їх платоспроможність та фінансову стабільність. Створення чіткої система внутрішньогосподарського контролю розрахунків 3 покупцями 
та замовниками дозволяє виявити порушення та помилки, невідповідності в розрахунках чинному законодавству, а також порушення умов договорів та термінів сплати за реалізовані товари, роботи, послуги.

Література

1. Міжнародний стандарт аудиту 315 «Ідентифікація та оцінка ризиків суттєвих викривлень через розуміння суб'єкта господарювання i його середовища». URL: http://www.mia.kiev.ua/ru/isa.html.

2. Волковицька О. М. Болтач С.Ю. Формування системи внутрішнього контролю розрахунків з покупцями та замовниками/ Волковицька О. М., Болтач С.Ю.// Електронне наукове фахове видання «Ефективна економіка», 2014. Випуск №12.

3. Гуцаленко Л. В. Внутрішньогосподарський контроль. [текст]: навч. посіб./ Л. В. Гуцаленко, М. М. Коцупатрий, У. О. Марчук - К.: «Центр учбової літератури», 2014. - 496 с.

4. Дорош Н. І. Внутрішній контроль та аудит в управлінні ризиками на підприємстві / Н. І. Дорош // Вісник Львівської комерційної академії. Серія: Економічна. - 2014. - Вип. 44. - С. 148-152.

5. Коцупатрий M. Внутрішньогосподарський контроль: організаційні аспекти та класифікаційні ознаки / М. Коцупатрий, У. Гуцаленко // Економічний аналіз. - 2010. - Випуск 6. - С. 433-436.

Стаття відправлена: 28.03.2017

(C) Копанчук К.B.

\section{ЦИТ: иа117-047 \\ DOI: 10.21893/2415-7538.2016-05-1-047 \\ УДК 657}

ОБЛІК ТА АНАЛІЗ ОСНОВНИХ ЗАСОБІВ

Ратушенко O.I.

Київський національний університет імені Тараса Шевченка, м. Київ, вул. Васильківська 90а, 03022

Ratushenko O.I.

\section{ACCOUNTING AND ANALYSIS OF FIXED ASSETS}

Taras Shevchenko National University of Kyiv, Kyiv, Vasilkivska 90a, 03022

Анотація. У статті розглянуто проблематику існування різних підходів до існуючої термінологї та визначення економічної сутності основних засобів в умовах гармонізації їх обліку основних засобів із міжнародними стандартами. Окреслено основні проблеми визначення термінів корисного використання основних засобів, порядок оцінки основних засобів при їх придбанні, переоцінці, списанні, реалізащії та подальшому використані, проблеми визначення ліквідаційної вартості окремих об'єктів основних засобів. Обгрунтовано необхідність подальщої розробки детальних інструктивних матеріалів з метою удосконалення обліку операцій з основними засобами. 